\title{
SISTEM INFORMASI BERPRESTASI BERBASIS WEB PADA SMP NEGERI 7 KOTA METRO
}

\author{
M.Arfa Andika Candra ${ }^{(1)}$ Ika Artahalia Wulandari ${ }^{(2)}$ \\ Jurusan Ilmu Komputer, Fakultas Ilmu Komputer,Universitas Muhammadiyah Metro \\ Jl.Gatot Subroto No.100 Yosodadi Kota Metro, Telpon :(0725)42445-Fax(0725)42454 \\ e-mail : ikaarthalia@gmail.com
}

\begin{abstract}
ABSTRAK
Tugas akhir ini merupakan hasil dari analisis dan observasi yang sedang berjalan dan Sistem Informasi Siswa Berprestasi Berbasis Web Pada SMP Negeri 7 Metro. Siswa yang berprestasi di bidang ekrakulikuler pada SMP Negeri 7 Metro sebagai sebuah program sekolah terlepas dari upaya untuk menghasilkan beberapa karya maupun prestasi di SMP Negeri 7 Metro, dalam kondisi saat ini pada SMP Negeri 7 Metro ditemui permaslahan dalam pengolahan data tentang siswa berprestasi yang diolah waka kesiswaan.Adapun permasalahan yang di hadapi yaitu pengolahan data siswa berprestasi masih di catat cara manual dan penyimpanan masih menggunakan buku,yang mengakibatkan muncul nya resiko,kerusakan dan menumpuk atau tumpang tindihnya data siswa berprestasi.Penyimpanan data seluruh siswa berprestasi dilakukan dalam 1 (satu) buku besar,sehingga waka kesiswaan masih kesulitan dalam pencarian data siswa berprestasi . Dalam perancangan sistem informasi kesiswaan ini penulis menggunakan 2 metode, yang pertama yaitu studi lapangan yang terdiri dari observasi, wawancara, dan dokumentasi. Sedangkan metode yang kedua yaitu studi putaka. Selain itu dalam perkembangan aplikasi penulis menggunakan aliran informasi, diagram conteks, data flow diagram, dan entitiy relationship diagram.sofware pendukung dalam aplikasi ini adalah MYSQL dan $p d f$. Perancangan sistem informasi siswa berprestasi menghasilkan rancangan input data siswa, data prestasi, dan data kelas serta outputnya berupa laporan data siswa berprestasi.
\end{abstract}

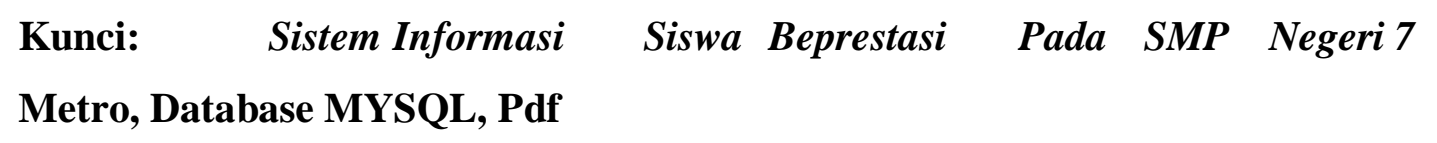




\section{PENDAHULUAN}

SMP Negeri 7 kota Metro adalah salah satu sekolah yang berada dikota. beralamat di Jl. Stadion 24 Kelurahan Tejosari Kecamatan Metro Timur. Melakukan tentang siswa berprestasi. Sejarah berdirinya Smp Negeri 7 Metro pada tanggal 17 januari 1959 kemudian pada tahun 1963 berganti nama menjadi Sekolah Teknik Persiapan Negeri, Berdasarkan SK Mendikbud RI No:067/0/94/ tanggal 2 April 1994 alih fungsi menjadi menjadi SMP Negeri 7 Metro beralamat di Jl. Kemiri no. 3 Kelurahan Iringmulyo Kecamatan Metro Timur dan kembali di rubah menjadi Pada tahun 2002, SMP Negeri 7 Metro direlokasi ke alamat yang baru yaitu di J1. Stadion 24 Kelurahan Tejosari Kecamatan Metro Timur yang dipimpin oleh ibu Repiyati, S.Pd. Mempunyai guru sebanyak 48 orang dan 22 kelas VII-IX dengan jumlah murid 618 siswa pada TA 2017/2018. Seperti SMP Negeri pada umumnya di indonesia masa pendidikan sekolah di SMP Negeri 7 Metro ditempuh dalam waktu tiga tahun pelajaran, mulai dari Kelas VII sampai Kelas IX. Hingga kini sekolah masih merupakan sekolah yang meluluskan lulusan-lulusan yang berpestasi baik bidang akademik maupun non akademik. Gedung semakin baik sebagai fasilitas penunjang pembelajaran dan kini sekolah ini menjadi sekolah yang besar. Siswa yang berprestasi di bidang ekrakulikuler pada SMP Negeri 7 Metro sebagai sebuah program sekolah terlepas dari upaya untuk menghasilkan beberapa karya maupun prestasi di SMP Negeri 7 Metro. Karya dan prestasi dibidang ekrakulikuler merupakan salah satu komponen penilaian dalam akreditasi sekolah. Karya dan prestasi dapat dihasilkan melalui kerja sama antara siswa dan guru,Siswa yang ada di program sekolah.Dalam prestasi disekolah itu dapat diperoleh melalui beberapa kompetisi baik local ataupun nasional. Prestasi ini berupa prestasi non akademik,prestasi non akademik dapat berasal dari unsur olahraga, seni dan lain-lain. Sedangkan karya dapat dihasilkan tanpa melalui kompetisi.karya dapat berupa hasil penelitian yang menghasilkan sebuah aplikasi berbasis komputer dan sebagainya. Dalam kondisi saat ini pada SMP Negeri 7 Metro ditemui permaslahan dalam pengolahan data tentang siswa berprestasi yang diolah waka kesiswaan.Adapun permasalahan yang di hadapi yaitu pengolahan data 
siswa berprestasi masih di catat cara manual dan penyimpanan masih menggunakan buku,yang mengakibatkan muncul nya resiko,kerusakan dan menumpuk atau tumpang tindihnya data siswa berprestasi.Penyimpanan data seluruh siswa berprestasi dilakukan dalam 1 (satu) buku besar, sehingga waka kesiswaan masih kesulitan dalam pencarian data siswa berprestasi.Penyimpanan data siswa berprestasi masih menggunakan buku besar mengakibatkan dalam pembuatan laporan siswa berprestasi untuk kepala sekolah mengalami keterlambatan dan kurang efektif.Aplikasi ini diharapkan dapat membantu pihak sekolah. Dengan kelebihan yaitu siswa yang berprestasi pada SMP Negeri 7 Metro dapat bisa mengatasi informasi yang tepat dan jelas di website sekolah agar mudah mencari tau tentang siswa berprestasi di SMP Negeri 7 Metro. Berdasarkan latar belakang permasalah yang telah dicantumkan diatas,maka dalam penyusunan tugas akhir ini penulis mengambil judul yang berkaitkan yaitu: "SISTEM INFORMASI SISWA BERPRESTASI BERBASIS WEB PADA SMP NEGERI 7 METRO”.

\section{KAJIAN PUSTAKA DAN LANDASAN TEORI}

\subsection{Definisi Sistem}

Pada dasarnya sistem adalah suatu kerangka dari prosedur-prosedur yang saling berhubungan, yang disusun sesuai dengan skema yang menyeluruh untuk melaksanakan suatu kegiatan atau fungsi utama dari perusahaan yang dihasilkan oleh suatu proses tertentu yang bertujuan untuk menyediakan informasi untuk membantu mengambil keputusan manajemen operasi perusahaan dari hari ke hari serta menyediakan informasi yang layak untuk pihak di luar perusahaan. Pengertian Sistem yang dikemukakan oleh para ahli adalah sebagai berikut: Pengertian Sistem Hanif (2007: 3) menyatakan sistem adalah "Kumpulan dari bagianbagian yang bekerja sama untuk mencapai tujuan yang sama atau Sekumpulan objek-objek yang saling berelasi dan berinteraksi serta hubungan antar objek bisa dilihat sebagai satu kesatuan yang dirancang untuk mencapai satu tujuan. Sistem dapat diartikan sebagai suatu kumpulan atau himpunan dari unsur atau variabel- 
variabel yang saling terorganisasi, saling berinteraksi, dan saling bergantung satu sama lain. Pengertian Sistem Menurut Harijono (2013:11) Sistem merupakan gabungan obyek yang memiliki hubungan secara fungsi dan hubungan antara setiap ciri obyek, secara keseluruhan menjadi suatu kesatuan yang berfungsi." Menurut Murdick, R.G, (2011 : 27) Suatu sistem adalah seperangkat elemen yang membentuk kumpulan atau prosedur-prosedur/bagan-bagan pengolahan yang mencari suatu tujuan bagian atau tujuan bersama dengan mengoperasikan data dan/atau barang pada waktu rujukan tertentu untuk menghasilkan informasi dan/atau energi dan/atau barang.

\subsection{Definisi Informasi}

Tidak mudah untuk mendefinisikan konsep informasi karena istilah yang satu ini mempunyai bermacam aspek, ciri, dan manfaat yang satu dengan yang lainnya terkadang sangat berbeda. Definisi dengan yang satu dengan yang Iain terkadang berlainan maknanya karena mempunyai penekanan dan versi yang berbeda. Informasi bisa jadi hanya berupa kesan fikiran seseorang atau mungkin juga berupa data yang tersusun rapi dan telah terolah. Berikut definisi dari para ahli. Menurut Sutaraman (2012:14) berpendapat informasi adalah sekumpulan data yang diorganisasikan dengan cara tertentu sehingga mereka mempunyai arti bagi si penerima. Menurut kadir (2008:31) informasi merupakan data yang telah diperoses sedemikian rupa sehingga meningkatkan pengetahuan orang yang menggunakan data tersebut. Berdasarkan beberapa pengertian para ahli maka dapat disimpulkan bahwa informasi adalah data yang telah diproses menjadi bentuk yang bernilai bagi penerimanya dan bermanfaat dalam setiap pengembailan keputusan. Menurut Sarosa(200:12) informasi merupakan data yang sudah mengalami pemerosesan sedemikian rupa sehingga dapat digunakan oleh penggunanya dalam membuat keputusan.

\subsection{Definisi Sistem Informasi}

Menurut kadir (2008:10) dalam 
bukunya yang berjudul SistemInformasi

Konsep dan Aplikasi: Informasi adalah sejumlah komponen (manusia, komputer, teknologi, informasi, dan prosedur kerja) dan dimaksut untuk mencapai sautu sasaran atau tujuan. Menurut ladjamudin (2009 : 13) sistem informasi adalah Suatu sistem yang dibuat oleh manusia yang terdiri dari komponen-komponen dalam organisasi untuk mencapai suatu tujuan yaitu mengendalikan organisasi. Sistem informasi menurut jugianto (2008: 11), adalah menjelaskan sistem informasi sebagai suatu sistem dalam susatu organisasi yang mempertemukan kebutuhan pengolahan transaksi harian, mendukung operasi,bersifat manajerial dan kegiatan strategi dari suatu organisasi, dan menyediakan pihak luar tertentu dengan laporan laporan yang diperlukan. Berdasarkan beberapa pendapat para ahli disimpulkan bahwa sistem informasi adalah sebuah sistem yang terdiri dari berbagai komponen yang saling bersatu untuk mencapai suatu tujuan yakni menyediakan sebuah informasi bagi yang membutuhkan

\subsection{Definisi Data}

Data berasal dari bahasa latin, datum

(tunggal), pemberian, karunia, sajian; data (jamak), hadiah-hadiah, sajiansajian. Untuk lebih memahami definisi tentang data berikut beberapa pendapat yang dikemukakan oleh para ahli antara lain: Kadir yang dikutip Triska Apriyani (2017:3) mendefinisikan data adalah "Fakta-fakta mentah yang mewakili kejadian-kejadian yang berlangsung dalam organisasi atau lingkungan fisik sebelum ditata dan diatur ke dalam bentuk yang dapat dipahami dan di gunakan orang”. Hartono yang dikutip Triska Apriyani (2017:2) "Data adalah kumpulan kejadian yang diangkat dari suatu kenyataan berupa angka-angka, huruf-huruf, atau simbol-simbol khusus atau gabungan darinya yang masih belum bisa bercerita banyak, sehingga perlu diolah lebih lanjut". Dari beberapa definisi diatas dapat disimpulkan bahwa data adalah suatu kejadian yang diangkat dari suatu kenyataan (fakta) dapat berupa angka-angka, huruf, simbol-simbol tertentu, atau gabungan dari ketiganya. Data belum dapat ditafsirkan sehingga perlu diolah agar menghasilkan informasi untuk pengambilan suatu keputusan.

\subsection{Definisi Pengolahan Data}


Menurut Jugiyanto Hartono yang dikutip Triska Apriyani (2017) dalam buku "Pengenalan Komputer" menyebutkan bahwa "Pengolahan data adalah manipulasi dari data ke dalam bentuk lebih berguna dan lebih berarti berupa suatu informasi dengan menggunakan suatu alat elektronik yaitu komputer". Dalam buku Jogiyanto yang dikutip Triska Apriyani (2017:2) yang berjudul "Pengenalan Komputer" menyebutkan bahwa "Pengolahan data adalah manipulasi dari data kedalam bentuk yang lebih berguna dan lebih berarti, berupa suatu informasi." Terdapat siklus pengolahan data yang terdiri dari 3 tahap yaitu dapat dilihat pada gambar 2.1. di bawah ini.

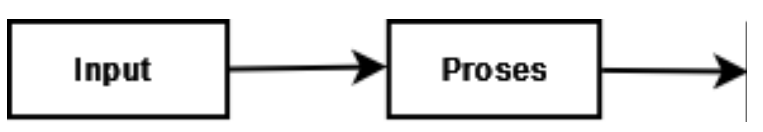

Gambar 2.1

Tampilan Siklus Pengolahan

Data (Sumber Jogiyanto 2017:2)

Data merupakan suatu kejadian yang menggambarkan kenyataan yang terjadi yang dimasukkan dalam elemen input dan kemudian akan diproses menjadi output sehingga menghasilkan informasi yang dibutuhkan.

Berdasarkan buku Warren Carl S. (2009:332) yang berjudul “Accounting Pengantar Akuntansi” menyebutkan bahwa "Pengolahan Data adalah waktu yang digunakan untuk menggambarkan bentuk data menjadi informasi yang memiliki kegunaan". Dari pengertian diatas dapat disimpulkan bahwa Pengolahan Data adalah cara mengolah bahan nyata untuk dijadikan dasar kajian, dan data itu akan di olah menjadi informasi yang berguna.

\subsection{Difinisi Internet}

Onno W. Purbo Tokoh pertama yang menjelaskan mengenai pengertian Internet adalah Purbo. Purbo (dalam Prihatna, 2005) menjelaskan bahwa Internet pada dasarnya merupakan sebuah media yang digunakan untuk mengefesiensikan sebuah proses komunikasi yang disambungkan dengan berbagai aplikasi, seperti Web, VoIP, Email. Allan (2005) Tokoh berikutnya, yaitu Allan (2005) menjelaskan bahwa internet merupakan sekumpulan jaringan komputer yang saling terhubung satu sama lain secara fisik dan juga memiliki kemampuan untuk membaca dan menguraikan berbagai 
protokol komunikasi tertentu yang sering kita kenal dengan istilah Internet Protocol (IP) serta Transmission Control Protocol (TCP).Protokol sendiri, lebih lanjut didefinisikan oleh Alan sebagai sebuah spesifikasi sederhana mengenai bagaimana dua atau lebih komputer dapat saling bertukar informasi. Strauss, El-Ansary, dan Frost (2003) Pengertian internet lainnya muncul dari pendapat yang dikemukakan oleh Strauss, El-Ansary, dan juga Frost (2003). Mereka mengatakan bahwa yang dimaksud dengan Internet adalah keseluruhan jaringan komputer yang saling terhubung satu sama lain. Beberapa komputer - komputer yang saling terhubung di dalam jaringan ini menyimpan dan juga memiliki beberapa file yang bisa diakses dan digunakan, seperti halaman web, dan juga data lainnya yang bisa digunakan dan juga diakses oleh berbagai komputer yang saling terhubung dengan Internet.

\subsection{Website}

Gregorius ( 2000: 30 ) Pengertian web menurut Gregorius adalah kumpulan halaman web yang saling terhubung dan file-filenya saling terkait. Web terdiri dari page atau halaman, dan kumpulan halaman dinamakan homepage. Hakim Lukmanul ( 2004 ) Pengertian website menurut Hakim Lukmanul adalah fasilitas internet yang menghubungkan dokumen dalam lingkup lokal maupun jarak jauh. Dokumen pada website disebut dengan web page dan link dalam website memungkinkan pengguna bisa berpindah dari satu page ke page lain ( hyper text ), baik diantara page yang disimpan dalam server yang sama maupun server diseluruh dunia. Pages diakses dan dibaca melalui browser seperti Netscape Navigator, Internet Explorer, Mozila Firefox, Google Chrome dan aplikasi browser lainnya. Hidayat ( 2010: 6 ) Pengertian website menurut Hidayat adalah keseluruhan halaman-halaan web yang terdapat dalam sebuah domain yang mengandung informasi.

\subsection{Definisi siswa}

Menurut Kompas, 1985 Siswa atau peserta didik merupakan mereka yang secara khusus diserahkan oleh kedua orang tuanya untuk mengikuti pembelajaran yang diselenggarakan disekolah, dengan tujuan untuk menjadi manusia yang berilmu pengetahuan, 
berketrampilan, berpengalaman, berkepribadian, berakhlak mulia dan mandiri. Menurut Jawa Pos, 1949 Siswa juga dapat dikatakan sebagai murid atau pelajar, ketika berbicara siswa makan fikiran kita akan tertuju kepada lingkungan sekolah, baik sekolah dasar maupun menengah. Menurut Gramedia, 2005 Siswa merupakan komponen masukan dalam system pendidikan, yang selanjutnya diproses dalam proses pendidikan, sehingga menjadi manusia yang berkualitas sesuai dengan tujuan pendidikan nasional.

\subsection{Definisi Prestasi}

Van de bos (2012:11), Prestasi adalah Suatu keahlian atau kemampuan spesifik yang dimiliki seseoranng. Magfr oh (2011:24) Prestasi Belajar adalah hasil dari seseorang dalam kegiatan pembelajaran. Kamus Bahasa Indonesia yang dinamakan Prestasi adalah hasil yang telah dicapai, dilakukan, dilakukan dan sebagainya.Muhibbin Syah (2010:15) Mengungkapkan bahwa Prestasi Merupakan suatu tingkat keberhasila seseorang dalam mencapai tujuan.

\subsection{Definisi Siswa Berprestasi}

Mendapat dukungan penuh dari komunitas serta memiliki linsensi

\begin{abstract}
Siswa berprestasi adalah anak didik yang selalu mengikuti aturan-aturan yang diteteapkan sekolah atau guru yang mendidik nya dan selalu mempunyai kewajiban apa yang telah menjadi tugas nya sebagai siswa untuk menjujung tinggi harkat dan marbatnya sebagai siswa berprestasi. itu rincian dari arti siswa dikalangan pendidikan.
\end{abstract}

\subsection{Pengertian Sublime Text}

Sublime Text adalah aplikasi editor untuk kode dan teks yang dapat berjalan diberbagai platformoperating system dengan menggunakan teknologi Phyton API. Terciptanya aplikasi ini terinspirasi dari aplikasi Vim, Aplikasi ini sangatlah fleksibel dan powerfull. Fungsionalitas dari aplikasi ini dapat dikembangkan dengan menggunakan sublimepackages. Sublime Text bukanlah aplikasi opensource dan juga aplikasi yang dapat digunakan dan didapatkan secara gratis, akan tetapi beberapa fitur pengembangan fungsionalitas (packages) dari aplikasi ini merupakan hasil dari temuan.

Mendapat dukungan penuh dari
komunitas serta memiliki linsensi


aplikasi gratis.

1. Sublime Text mendukung berbagai bahasa pemrograman dan mampu menyajikan fitur syntax highlight hampir di semua bahasa pemrogramman yang didukung ataupun dikembangkan oleh komunitas seperti; $C, C++$, C\#, CSS, D, Dylan, Erlang, HTML, Groovy, Haskell, Java, JavaScript, LaTeX, Lisp, Lua, Markdown, MATLAB, OCaml, Perl, PHP, Python, R, Ruby, SQL, $T C L$, Textile and $X M L$. Biasanya bagi bahasa pemrograman yang didukung ataupun belum terdukung secara default dapat lebih dimaksimalkan atau didukung dengan menggunakan add-ons yang bisa didownload sesuai kebutuhan user. Berikut beberapa fitur yang diunggulkan dari aplikasi Sublime Text:

2. Goto AnythingFitur yang sangat membantu dalam membuka file ataupun menjelajahi isi dari file hanya dengan beberapa keystrokes.

3. Multiple SelectionsFitur ini memungkinkan user untuk mengubah secara interaktif banyak baris sekaligus, mengubah nama variabel dengan mudah, dan memanipulasi file lebih cepat dari sebelumnya.

4. Command PalleteDengan hanya beberapa keystorkes, user dapat dengan cepat mencari fungsi yang diinginkan, tanpa harus menavigasi melalu menu.

5. Distraction Free ModeBila user memerlukan fokus penuh pada aplikasi ini, fitur ini dapat membantu user dengan memberikan tampilan layar penuh.

6. Split EditingDapatkan hasil yang maksimal dari monitor layar lebar dengan dukungan editing perpecahan. Mengedit sisi file dengan sisi, atau mengedit dua lokasi di satu file. Anda dapat mengedit dengan banyak baris dan kolom yang user inginkan.

7. Instant Project SwitchMenangkap semua file yang dimasukkan kedalam project pada aplikasi ini. Terintegrasi dengan fitur Goto Anything untuk menjelajahi semua file yang ada ataupun untuk beralih ke file dalam project 
lainnya dengan cepat

8. Plugin APIDilengkapi dengan plugin API berbasis Phyton sehingga membuat aplikasi ini sangat tangguh.

9. Customize AnythingAplikasi ini memberikan user fleksibilitas dalam hal pengaturan fungsional dalam aplkasi ini.

10. Cross PlatformAplikasi ini dapat berjalan hampir disemua operating system modern seperti Windows, OS X, dan Linux based operating system.

\subsection{Bahasa Pemograman (WEB)}

PHP adalah kependekan dari PHP: Hypertext Preprocessor. Sedangkan pengertian $P H P$ adalah bahasa pemrograman web server-side yang bersifat open source. PHP merupakan script yang terintegrasi dengan $H T M L$ dan berada pada server (server side HTML embedded scripting). PHP adalah script yang digunakan untuk membuat halaman website yang dinamis. Dinamis berarti halaman yang akan ditampilkan dibuat saat halaman itu diminta oleh client. Mekanisme ini menyebabkan informasi yang diterima client selalu yang terbaru atau up to date. Semua script PHP dieksekusi pada server di mana script tersebut dijalankan.

\section{METODE}

Metodelogi adalah kesatuan, atau prosedur, konsep-konsep, pekerjaan atau aturan yang digunakan oleh suatu ilmu pengetahuan. Dalam memperoleh data guna menyusun Tugas Akhir ini, penulis menggunakan metode yaitu sebagai berikut:

- Studi Lapangan

Studi Lapangan adalah pengumpulan data yang secara langsung mempelajari yang berkaitan dengan masalah yang sedang dihadapi. Adapun studi lapangan yang penulis lakukan adalah dengan teknik:

- Pengamatan (Observasi)

Yaitu metode pengumpulan data dengan cara melakukan pengamatan secara langsung pada SMP Negeri 7 Metro, sehingga penulis dapat mengetahui sistem yang sedang berjalan pada saat ini. (Terlampir foto-foto Penelitian).

- Wawancara (Interview)

Yaitu metode pengumpulan data dengan cara melakukan komunikasi dan tanya jawab secara langsung dengan Bpk Unyah Sanjaya, S.Pd. sebagai Guru 
kesiswaan di SMP Negri 7 Metro. (Terlampir Tabel Wawancara Penelitian).

- Dokumentasi (Dokumentation)

Yaitu metode pengumpulan data dengan cara mencari data-data dari catatan, dokumentasi, dokumen atau arsip di SMP Negeri 7 Metro. (Terlampir data/dokumen Penelitian)

- Studi Pustaka

Studi pustaka adalah segala sesuatu yang dilakukan oleh peneliti untuk menghimpun informasi yang relevan dengan topik atau masalah yang sedang diteliti. Yaitu dengan cara mengumpulkan data dengan membaca buku-buku dan mempelajari literatur yang berkaitan dengan masalah yang sedang dihadapi.

\section{PEMBAHASAN}

\subsection{Hasil Penelitian}

Dalam kondisi saat ini pada SMP Negeri 7 Metro ditemui permaslahan dalam pengolahan data tentang siswa berprestasi yang diolah waka kesiswaan. Adapun permasalhan yang di hadapi yaitu pengolahan data siswa berprestasi masih di catat cara manual dan penyimpanan masih menggunakan buku, yang mengakibatkan muncul nya resiko kehilangan, kerusakan dan numpuk atau tumpang tindihnya data siswa berprestasi. Penyimpanan data seluruh siswa berprestasi dilakukan dalam 1 (satu) buku besar, sehingga waka kesiswaan masih kesulitan dalam pencarian data siswa berprestasi. Penyimpanan data siswa berprestasi msih menggunakan buku besar mengakibatkan dalam pembuatan laporan siswa berprestasi untuk kepala sekolah mengalami keterlambatan dan kurang efektif.

\subsection{Gambaran Umum Sistem Yang Diusulkan}

Aplikasi yang diusulkan memiliki beberapa keunggulan dari sistem yang sedang berjalan. Sistem yang diusulkan lebih mudah digunakan. Lebih memperhemat waktu dalam proses pengolahan data siswa berprestasi yang tersimpan di database. Sehingga dapat mempermudah dalam proses pembuatan 
laporan. Pada tahapan perancangan prosedur ini bertujuan untuk menghasilkan Sistem Iinformasi siswa berprestasi menggunakan web. Adapun perancangan proses ini mencakup aliran sistem informasi, diagram konteks, data flow diagram, flowchart, yang dapat menjelaskan aliran data yang diproses hingga menghasilkan informasi yang diinginkan.Aliran informasi yang diusulkan tidak merubah tujuan ataupun fungsi dari sistem informasi yang berjalan. Beberapa perubahan di dalam pengolahan data siswa berprestasi dilakukan untuk membuat sistem yang lebih baik. Berikut adalah aliran informasi yang diusulkan: Aliran informasi pengolahan data prestasi yang dimulai dari tata usaha memasukan data siswa yang berprestasi kemudian tata usaha memproses data siswa,setelah tata usaha memasukan data siswa berprestasi,siswa memasukan data prestasi nya setelah siswa memasukan data prestasi nya diproses oleh waka kesiswaan dan waka kesiswaan melakukan pengecekan data siswa yang berpretasi kemudian setelah sudah pengecekan selesai ,waka kesiswaan menerima dan pemembuat laporan kemudian melaporkan kepada kepala sekolah

\subsection{Rancangan Diagram Konteks}

Diagram konteks adalah diagram yang terdiri dari suatu proses dan menggambarkan ruang lingkup suatu sistem. Rancangan menggambarkan diagram konteks pendaftaran pasien umum.

\subsection{Rancangan Data Flow Diagram}

Data Flow Diagram (DFD) merupakan peralatan yang berfungsi untuk menggambarkan secara rinci mengenai sistem sebagai jaringan kerja antar fungsi yang berhubungan satu sama lain dengan menunjukkan dari dan kemana data mengalir serta penyimpanannya. 
Jurnal Mahasiswa IImu Komputer (JMIK) Vol. 01, No. 01, Maret 2021

1) Rancangan Data Flow Diagram (DFD) Level 0

\subsection{Rancangan Flowchart}

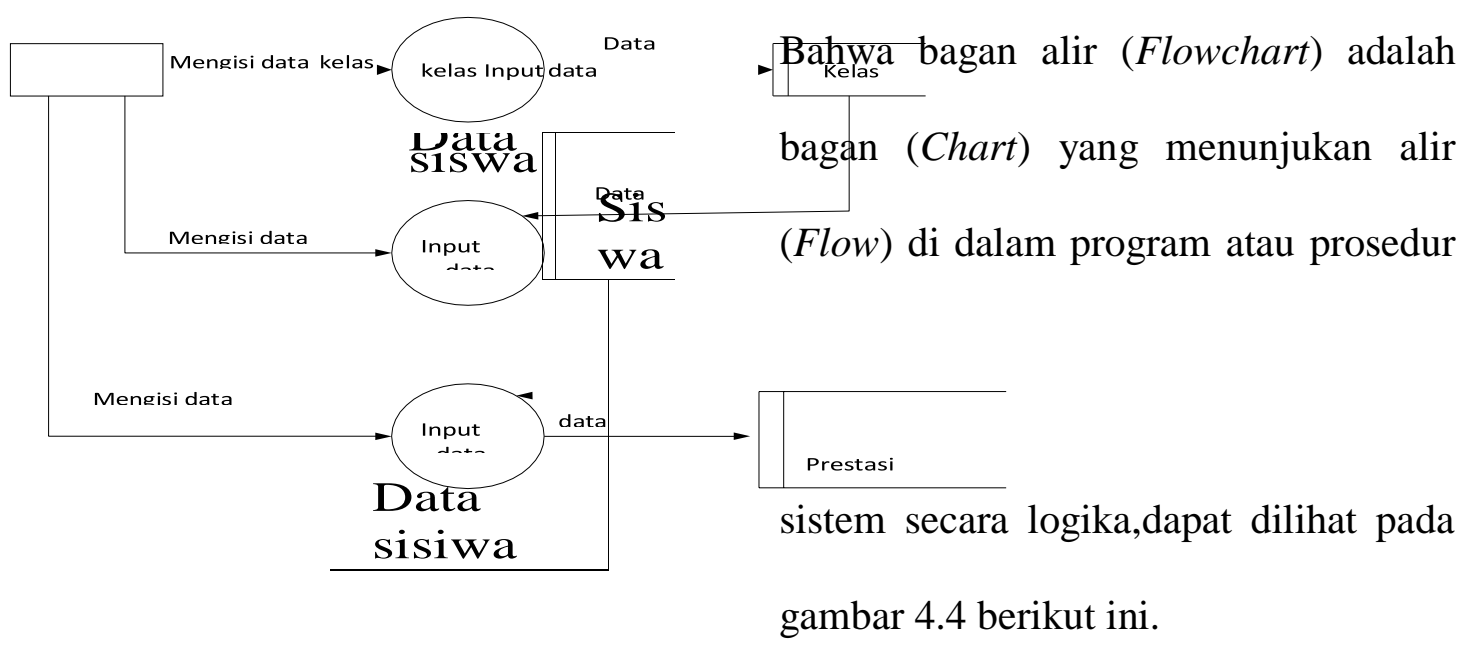

Gambar 4.2. Rancangan

Data Flow Diagram

(DFD) Level 0

2) Rancangan Data

Flow Diagram

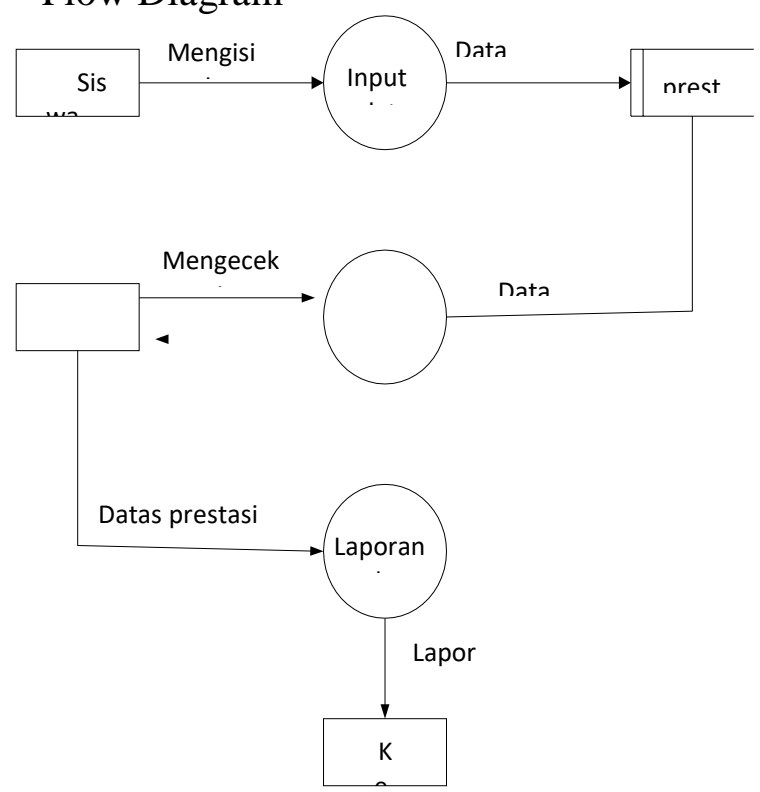

(DFD) Level 1

Gambar 4.3 Rancangan

Data Flow Diagram

(DFD) Level 1 


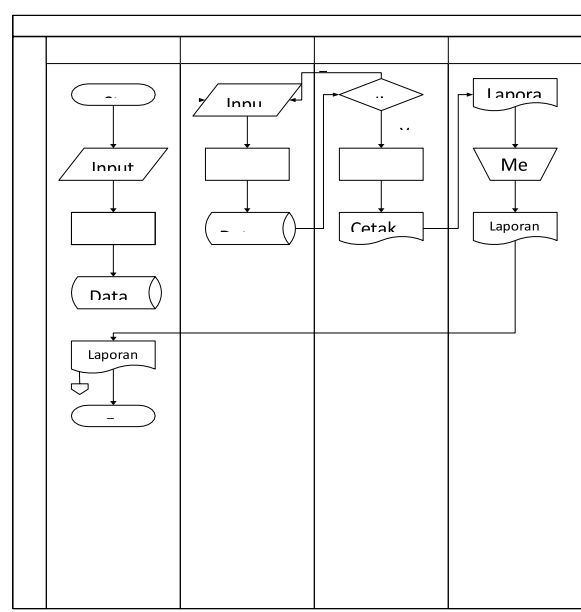

Gambar 4.4 Flowchart

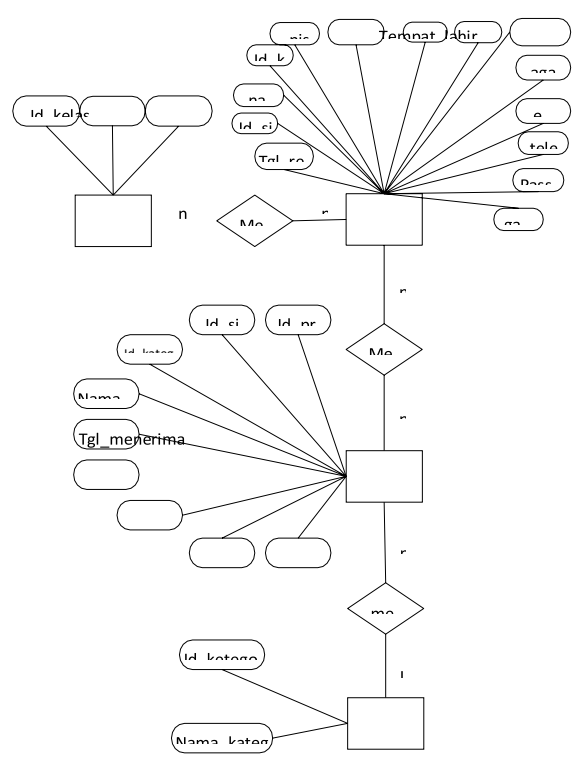

\subsection{Entity Relationship Diagram (ERD)}

Entity Relentionship Diagram adalah alat pemodelan data utama dan akan membantu mengorganisasi data dalam satu proyek kedalam entitas-entitas dan menentukan hubungan antar entitas. Proses memungkinkan analis menghasilkan struktur basisdata yang baik sehingga dapat disimpan dan diambil secara efisien.dapat dilihat pada gambar 4.5
Gambar 4.5 Entity Relentionship Diagram(ERD)

\subsection{Rancangan Basis Data}

Tahapan ini merupakan tahap dimana penulis menempatkan datadata pada penyimpanan yang akan diproses. Tempat penyimpanan untuk menampung data tersebut dengan database, database dapat diumpamakan sebagai sebuah tempat penyimpanan data yang terstruktur agar dapat diakses dengan cepat dan mudah dalam Sistem Informasi Siswa berprstasi pada SMP Negeri 7 Metro. Penulis 
memuat file Database sebagai

berikut:

\section{Tabel Users}

Adapun tabel users yang

digunakan untuk menyimpan data

users yang telah diinput seperti

tabel 4.1Nama Tabel

\begin{tabular}{|l|l|l|l|l|}
\hline Nama Field & Type Data & Lenght & Null & Primary \\
\hline Id_users & Int & 11 & No & Yes \\
\hline Nip & Int & 11 & No & \\
\hline Nama & \multirow{2}{*}{$\begin{array}{l}\text { Varchar } \\
\text { Tempat_lah }\end{array}$} & 50 & Yes & \\
\cline { 1 - 3 } ir & Varchar & 100 & Yes & \\
\cline { 1 - 1 } Tgl_lahir & Date & & Yes & \\
\hline Gende & Tinyint & 1 & No & \\
\hline Alamat & Text & & Yes & \\
\hline
\end{tabular}

\section{KESIMPULAN}

\section{Kesimpulan}

Setelah memahami dan menganalisa masalah yang terjadi maka penulis dapat merancang Aplikasi siswa berprestasi menggunakan pemograman $\begin{array}{llll}\text { berbasis web Smp Negeri } 7 & \end{array}$ Metro.Sehingga dapat diambil beberapa kesimpulan sebagai berikut:.

- Sistem Informasi siswa berprestasi di rancang dengan
DFD, ERD dan disertai database MySQL.

- Proses pencarian data data siswa dibuat lebih mudah dengan menggunakan kunci pencarian Nis

\section{Saran}

Berdasarkan kesimpulan di atas penulis memiliki saran sebagai berikut :

- Dalam pembuatan aplikasi ini, penulis berharap agar aplikasi ini dapat dikembangan menjadi lebih lagi kedepannya dan penulis membuat aplikasi ini sesuai dengan pengamatan yang dilakukan di Smp Negeri 7 Metro terhadap sistem perlu diperhatikan agar sistem ini dapat beroperasi secara maksimal.

- Jika dalam pembuatan aplikasi ini terdapat suatu kekurangan, khususnya dalam hal desain antar muka penulis berharap untuk pengembangan lebih lanjut dapat ditingkatkan.

- Memantau efektifitas dan efisiensi program untuk pengembangan program selanjutnya guna 
Jurnal Mahasiswa IImu Komputer (JMIK) Vol. 01, No. 01, Maret 2021

mengantisipasikebutuhan sistem dimasa yang akan datang.

[5]

Hakim Lukmanul ( 2004 ).

Modul Pemograman Web. Jakarta : Modula

\section{DAFTAR PUSTAKA}

[1] Hanif. (2012). Sistem Informasi Pengolahan Data Negeri Tanjung, KecamatanTanjung Gandang, Kabupaten Sijujung Berbasis Web. Jurnal Edik Informatika Penelitian Bidang Komputer Sains dari Pendidikan Informatika V2. i2. ISSN : 2407-0491

[2] H.M JugSianto,dikutip Hartono. (2017).Aplikasi Pengolahan Data Penjualan dan Profit Pada Traffix Distro Pacitan. Indonesia Jurnal on Computer Scince Speed IJCSS - Volume 10 No.4. ISSN : 1979-9330

[3] Van de bos (2012:11),Sistem Informasi Kegiatan Belajar Mengajar Berbasis Web. Jurnal on Software Engineering Volume. 2 No. 1, 2016

[4] Widianti, Utami Dewi.(2012). Pembangunan Sistem Informasi Aset Di Pt.Industri Telekomunikasi Indonesia (Persero) Berbasis Web, Jurnal Ilmiah Komputer dan Informatika Volume. 1 No. 2, 2012, 60

[6] Hidayat ( 2010: 6 ). Pemanfaatan Sistem Informasi Perpustakaan Digital Berbasi Website . Indonesia Jurnal on Sofware Egineeng Volume. 1 No 1.ISSN : 2461-0690

[7] Michael Widenius. (2016). Analisa dan Perancangan Sistem Replika Database MSQL Dengan Menggunakan Vmware pada Sistem Operasi Open Source Jurnal Operasi dan Teknologi. Volume 1 No. 2 ISSN 2640-7840

[8] Warren Carl S. (2009:332) Accounting Pengantar Akuntansi jakarta : Modula

[9] Sarintan Kaharu,Oki Sakina (2016) Perancangan Sistem Informasi Pengolahan Data Akademik pada TK Asiyah. Volume. 3 No 4. ISSN 25074587

[10] Hartono yang dikutip Triska Apriyani (2017:2) Basis Data Bandung : Informatika Bandung. 